\title{
Hemoglobin Function in Stored Blood
}

\author{
H. Franklin Bunn, Mary H. May, Walter F. Kocholaty, and \\ Charles E. Shields \\ From the Blood Transfusion Division, U.S. Army Medical Research \\ Laboratory, Fort Knox, Kentucky 40121, and the Biochemistry Division, \\ U.S. Army Medical Research Laboratory, Fort Knox, Kentucky 40121
}

A B S T R A C T Serial oxygen dissociation curves were performed on blood units preserved in acid-citrate-dextrose (ACD), ACD-adenine, and ACD-adenine-inosine. Dividing blood from a single donor into two or more bags allowed direct comparison between preservatives. During the 1st wk of storage in ACD, a progressive increase in oxygen affinity was observed. Thereafter, little further change was noted. Oxygen affinity increased even more rapidly during initial storage in ACD-adenine. However, with the inclusion of inosine as a preservative, oxygen affinity remained unaltered during the first $2 \mathrm{wk}$. Increases in oxygen affinity correlated well with falling levels of red cell 2,3-diphosphoglycerate (2,3-DPG) during storage. No significant changes in glutathione, reduced form $(\mathrm{GSH})$, or $\mathrm{A} 3\left(\mathrm{Ar}_{\mathbf{I}}\right)$ hemoglobin levels were noted during the first $3 \mathrm{wk}$ of storage. No significant accumulation of ferrihemoglobin was detected. When blood stored 20 days in ACD or ACD-adenine was incubated with inosine for $60 \mathrm{~min}$ at $37^{\circ} \mathrm{C}, 2,3-\mathrm{DPG}$ and adenosine triphosphate (ATP) were resynthesized, and oxygen affinity was decreased. The distribution of 2,3-DPG in fresh and stored red cells appeared to influence experimental values for Hill's $n$, a measure of heme-heme interaction.

\section{INTRODUCTION}

The ultimate aim in transfusing blood is the maintenance or restoration of a medium for the transport of oxygen to body tissues. Most often, the efficacy of transfusion therapy is evaluated by survival of the donor erythrocytes in the recipient. However, red cells may have a normal in vivo survival yet be unable to bind and unload oxygen physiologically. In 1956, Valtis and Kennedy found that blood stored more than a few days in acid-citrate-dextrose (ACD) showed a significant increase in oxygen affinity (1). This alteration in hemoglobin function gradually abated several hours after

\footnotetext{
Received for publication 12 August 1968
}

transfusion. Massive transfusion therapy is becoming increasingly frequent for both combat casualties and patients requiring other forms of extensive surgery. $\mathrm{Re}$ placement with blood having an abnormally high oxygen affinity could have significant consequences, particularly in a patient whose capability for physiologic adaptations may be severely compromised.

The purpose of this study was twofold. First, it seemed desirable to study the hemoglobin function of blood stored in ACD supplemented with adenine since this additive has received considerable recent attention from military (2) and civilian centers $(3,4)$. Accordingly, we have obtained serial oxygen dissociation curves on paired units of ACD blood, stored with and without adenine. In addition the effect of inosine was studied in a similar way. Secondly, we have measured various other factors known to affect hemoglobin function in an attempt to delineate the mechanism by which oxygen affinity increases during storage.

\section{METHODS}

Blood was collected from 12 healthy young male volunteers, none of whom smoked, and was stored in sterile plastic bags ${ }^{1}$ at $4 \pm 1^{\circ} \mathrm{C}$. In all the experiments, the blood from each donor was divided into two (or sometimes three) separate bags containing different preservatives. The composition of the preservatives used in this study is shown in Table I. At regular intervals during storage aliquots of blood were withdrawn aseptically for testing.

Whole blood oxygen dissociation curves were performed by an adaptation of the method of Peters and Van Slyke (5) which is described in detail elsewhere (6). In brief, whole blood was equilibrated with gas mixtures in a $250 \mathrm{mlcylindrical}$ tonometer which rotated on its longitudinal axis in a $37^{\circ} \mathrm{C}$ water bath. The gas mixtures were saturated with water vapor and contained a constant partial pressure of carbon dioxide $(40 \mathrm{~mm} \mathrm{Hg})$ and varying proportions of oxygen and nitrogen. After a 20 min equilibration the oxygen content of the blood was measured with the Van Slyke manometric apparatus (5). Blood $\mathrm{pH}$ was measured anaerobically at $37^{\circ} \mathrm{C}$ with a glass electrode. ${ }^{2}$ The total hemoglobin concen-

1 Fenwal Incorporated, Ashland, Mass.

2 Instrumentation Laboratory Inc., Watertown, Mass. 
TABLE I

Concentration of Preservatives in Stored Blood Units

\begin{tabular}{|c|c|c|c|}
\hline Preservative* & $d$-Glucose & Adenine & Inosine \\
\hline & \multicolumn{3}{|c|}{ $\mu$ moles $/ m l$ whole blood } \\
\hline “Citrate" $\ddagger$ & - & 一 & - \\
\hline $\mathrm{ACD} \S$ & 16.2 & - & - \\
\hline ACD-adenine§ & 16.2 & 0.47 & - \\
\hline ACD-adenine-inosine $\|$ & 16.2 & 0.47 & 15.0 \\
\hline
\end{tabular}

ACD, acid citrate dextrose.

* All blood specimens were anticoagulated with acid citrate. ‡ Identical with ACD (NIH Formula A) except that preservative lacks $d$-glucose.

\& Fenwal Incorporated, Ashland, Mass.

\|Inosine added to full unit of ACD-adenine immediately after collection.

tration was determined from the absorbance at $540 \mathrm{~m} \mu$ of an appropriate dilution in Drabkins solution. The partial oxygen pressure $\left(\mathrm{PO}_{2}\right)$ of a sample of the equilibrating gas mixture was measured by an amperometric blood gas analyzer. ${ }^{2} \mathrm{Po}_{2}$ was corrected to a whole blood $\mathrm{pH}$ of 7.40 by the Severinghaus nomogram $\left(\frac{\Delta \log \mathrm{Po}_{2}}{\Delta \mathrm{pH}}=-0.43\right)(7)$. Oxygen dissociation curves were drawn from points determined by five to seven equilibrations. These data were graphed logarithmically according to the Hill equation:

$$
\log \left(\frac{y}{1-y}\right)=n \log \mathrm{Po}_{2}+\log K
$$

where $y$ is

$$
\frac{\% \text { oxygen saturation }}{100}
$$

or

(oxyhemoglobin)

$$
\text { (oxyhemoglobin + deoxyhemoglobin), }
$$

$\mathrm{Po}_{2}$ is the partial pressure of oxygen, and $n$ is an expression of "heme-heme interaction." When the data are plotted in this way, a straight line is obtained, within the limits of experimental error. $n$ is determined by the slope of the line; $P_{50}$ or the $\mathrm{Po}_{2}$ at which hemoglobin is half saturated with oxygen is obtained from the intercept of the line at the abscissa $\left(\log \frac{y}{1-y}=0\right)$. Carboxyhemoglobin was not measured

in the stored units, since the levels are very low in nonsmokers (8), and there is no significant accumulation of carboxyhemoglobin during the first 30 days of storage $(1,9)$.

Whole blood oxygen dissociation curves were run on fresh blood samples from 15 volunteers. $\overline{\mathrm{P}}_{50}$ value was $25.7 \pm 0.35$ (SEM) $\mathrm{mm} \mathrm{Hg}$, while the mean $n$ value was $2.36 \pm 0.063$ (SEM). There was no difference in the oxygen dissociation curves of heparinized fresh blood compared to fresh blood collected in ACD, after the data were corrected to a standard $\mathrm{pH}(7.40)$ in agreement with the results of Valtis and Kennedy (1). Using similar methods Bromberg and Jensen have reported $\overline{\mathrm{P}}_{50}$ value for fresh heparinized blood of $25.2 \pm 0.33$ (SEM) $\mathrm{mm} \mathrm{Hg}$ and a mean $n$ value of 2.40 \pm 0.071 (SEM) (10), while Bartels and associates obtained the following: $P_{50}=26.1 \pm 0.36$ (SEM) $\mathrm{mm} \mathrm{Hg}$ and $n=2.67$ \pm 0.078 ( SEM) (11).
In one experiment oxygen dissociation curves were also performed spectrophotometrically on hemolysates by the method of Rossi Fanelli and Antonini (12). Nondialyzed hemoglobin solutions of approximately $7.0 \mathrm{mg} / \mathrm{ml}$ in $0.1 \mathrm{M}$ PO، buffer, $\mathrm{pH} 7.4,20^{\circ} \mathrm{C}$, were equilibrated in a tonometercuvette with a $0.1 \mathrm{~cm}$ light path.

Blood 2,3-diphosphoglycerate (2,3-DPG) and adenosine triphosphate (ATP) levels were measured in duplicate by the microfluorometric method of Lowry, Passonneau, Hasselberger, and Schultz (13) as modified by Keitt (14). The mean level of 2,3-DPG in fresh ACD blood specimens from 18 individuals was $4.55 \pm 0.12$ (SEM) $\mu \mathrm{moles} / \mathrm{ml}$ of $\mathrm{RBC}$, while the mean ATP level was $1.34 \pm 0.033$ (SEM) $\mu$ moles/ $\mathrm{ml}$ of RBC. These results agree well with normal values obtained in Keitt's laboratory. A neutralized protein-free extract was always prepared from an aliquot of blood on which an oxygen dissociation curve was performed and stored at $-20^{\circ} \mathrm{C}$. The specimens for a given experiment were all analyzed together at a later date. There was no detectable change in 2,3-DPG or ATP levels of specimens preserved in this manner.

Blood levels of reduced glutathione (GSH) were determined by the method of Beutler, Duron, and Kelly, using 5,5'-dithiobis-2-nitrobenzoic acid (DTNB) as the color developer (15). The mean value for fresh blood specimens collected in ACD was $2.31 \pm 0.10$ (SEM) $\mu \mathrm{moles} / \mathrm{ml}$ of $\mathrm{RBC}$, which is in good agreement with the results of others (16).

A3 $\left(A_{I}\right)$ hemoglobin was determined by the method of Allen, Schroeder, and Balog (17). Hemolysates were chromatographed on Amberlite (CG-50) with developer 2. Under these conditions the hemoglobins having a faster mobility than the preponderant A hemoglobin were eluted as a single peak. No correction was made for the small amount of hemoglobin $\mathrm{F}$ which had a mobility similar to A3 under these conditions. Further fractionation of A3 hemoglobin was not attempted.

Blood ferrihemoglobin determinations were done by the method of Evelyn and Malloy (18).

Fresh red cells were separated by ultracentrifugation on the basis of relative densities as described by Edwards and Rigas (19). After removal of the buffy coat, heparinized blood was centrifuged in $15-\mathrm{ml}$ plastic tubes at $65,000 \mathrm{~g}$ for $60 \mathrm{~min}$ at $4^{\circ} \mathrm{C}$. Approximately $0.25 \mathrm{ml}$ of packed red cells were removed from the top and bottom layers by puncturing the tube with a 21 gauge needle at the appropriate level.

\section{RESULTS}

When blood was stored in either ACD or ACD-adenine, there was a prompt rise in oxygen affinity, shown in Fig. 1 by a decrease in $P_{s o}$, the partial pressure of oxygen at which hemoglobin is half saturated. In experiments on blood from three different donors, the $P_{s_{0}}$ fell more rapidly in $A C D$-adenine blood than in the paired ACD unit. After about 7 days, there was little further increase in oxygen affinity. The addition of inosine to ACD-adenine blood at the time of collection had a marked effect on hemoglobin function (Fig. 2). In each of three paired experiments, blood preserved with inosine maintained near normal oxygen affinity for 10-20 days, while the same blood stored without inosine showed the expected prompt rise in oxygen affinity.

The oxygen affinity data shown in Figs. 1 and 2 were 


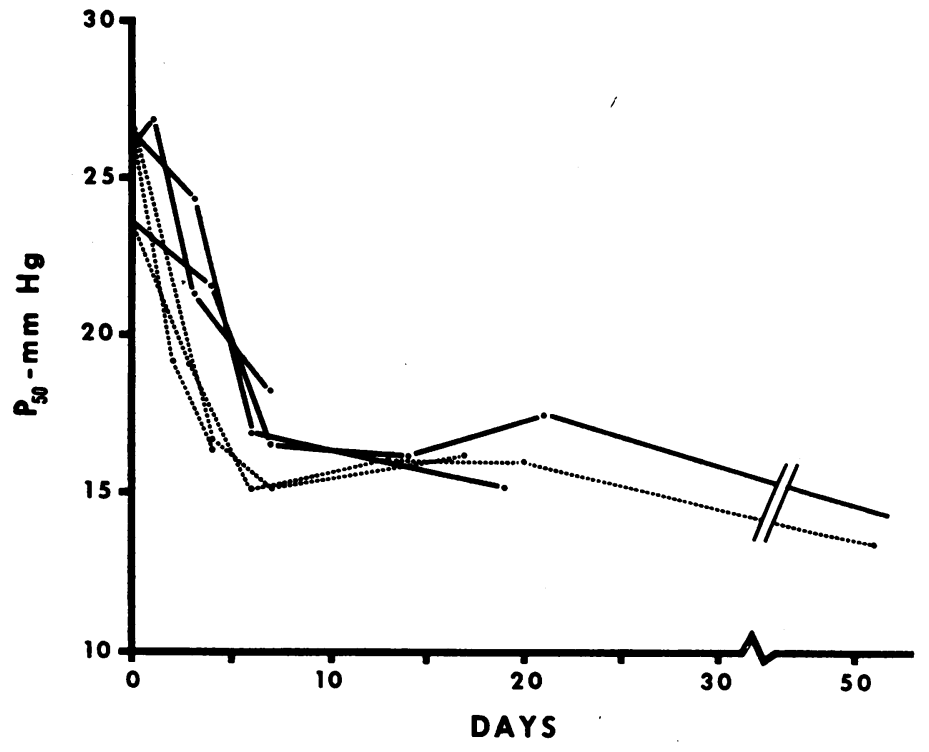

FIGURE 1 Change in oxygen affinity during storage of blood preserved in acid citrate dextrose (ACD) $(-)$ and ACD-adenine $(\cdots \cdots) . P_{50}$ represents the partial pressure of oxygen at which hemoglobin is half saturated. corrected to a $\mathrm{pH}$ of 7.40 on the basis of whole blood $\mathrm{pH}$ determinations. Measurement of intracellular $\mathrm{pH}$ would have allowed a more precise correction since plasma and intracellular $\mathrm{pH}$ may not change proportionately during blood storage. Secondly, published figures for $\Delta \log \mathrm{Po}_{2} / \Delta \mathrm{pH}$ vary considerably (9). The value employed in this study $(-0.43)$ is close enough to that used by Valtis and Kennedy $(-0.47)$ to allow valid comparisons (1). Finally the relationship between $\log \mathrm{Po}_{2}$ and whole blood $\mathrm{pH}$ may not be truly linear over the wide $\mathrm{pH}$ range encountered in this study (1). For these reasons the oxygen affinity data reported in Figs. 1 and 2 may be subject to systematic error, but it is probably not large since the $P_{50}$ values obtained here with ACD blood agree well with previous studies (1, 9).

Changes in the $\mathrm{pH}$ of paired units during 30 days of storage are shown in Table II. Both fresh and stored blood showed the expected inverse relationship between $\mathrm{pH}$ and degree of oxygenation, a manifestation of the Bohr effect. Carbon dioxide dissociation curves have also indicated that the Bohr effect was preserved in blood stored in ACD (1).

During the 1st wk of storage in ACD and ACDadenine there was considerable fluctuation in the values for Hill's $n$ calculated from the oxygen dissociation

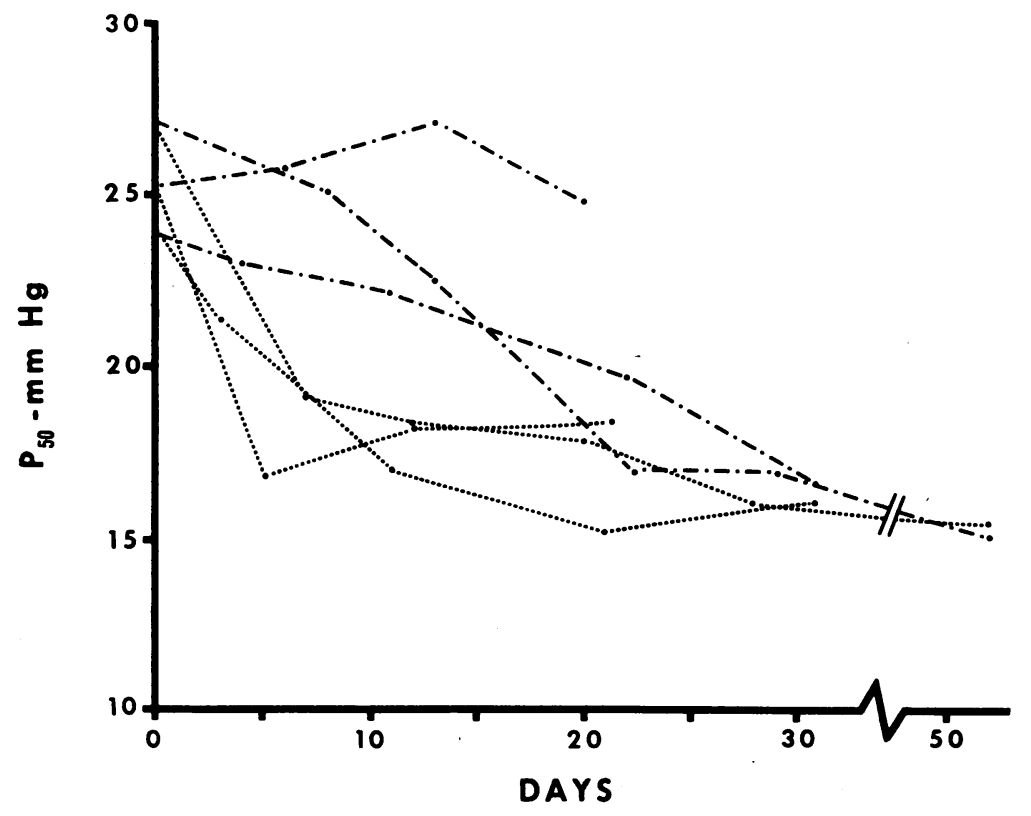

FIGURE 2 Changes in oxygen affinity during the storage of blood preserved in either ACD-adenine $(\cdots \cdots)$ or ACD-adenineinosine (-.-.-). 
TABLE II

Effect of Oxygenation on the $p H$ of Fresh and Stored Blood

\begin{tabular}{|c|c|c|c|c|}
\hline $\begin{array}{l}\text { Donor: } \\
\text { St. }\end{array}$ & $\begin{array}{l}\text { Oxyhemo- } \\
\text { globin } \\
\text { saturation }\end{array}$ & $A C D$ & $\begin{array}{l}\text { ACD- } \\
\text { adenine }\end{array}$ & \\
\hline \multirow{3}{*}{ Day 0} & $\%$ & & & \multirow[b]{6}{*}{$\begin{array}{l}\text { ACD- } \\
\text { adenine- } \\
\text { inosine }\end{array}$} \\
\hline & 0 & 7.01 & 7.02 & \\
\hline & 100 & 6.90 & 6.92 & \\
\hline \multirow[t]{2}{*}{ Day 20} & 0 & 6.78 & 6.80 & \\
\hline & 100 & 6.71 & 6.73 & \\
\hline $\begin{array}{c}\text { Donor: } \\
\text { Fo. }\end{array}$ & & & $\begin{array}{l}\text { ACD- } \\
\text { adenine }\end{array}$ & \\
\hline \multirow[t]{2}{*}{ Day 0} & 0 & & 7.05 & 7.04 \\
\hline & 100 & & 6.97 & 6.96 \\
\hline \multirow[t]{2}{*}{ Day 20} & 0 & & 6.80 & 6.72 \\
\hline & 100 & & 6.73 & 6.66 \\
\hline
\end{tabular}

curves. During the next 2 wk, however, there was a gradual increase. By 21 days of storage the mean value for $n$ had risen to $2.58 \pm 0.052$ (SEM) as compared to the mean of $2.36 \pm 0.063$ (SEM) on the day of collection $(P>0.05))^{3}$ In two paired units stored in ACD and ACD-adenine for $8 \mathrm{wk}$ the $n$ values rose to 3.0 and 3.1 , respectively.

No significant accumulation $(<1 \%)$ of ferrihemoglobin was found in blood stored for 8 wk with the preservatives listed in Table I.

No significant change in A3 hemoglobin levels was observed during $8 \mathrm{wk}$ of storage in either ACD or $\mathrm{ACD}$-adenine (Fig. 3). In aliquots stored without glucose ("citrate" units) a slight rise in A3 hemoglobin levels occurred by the 6th wk of storage.

In aliquots of blood stored without any substrate ("citrate" units), there was a fall in GSH by $4 \mathrm{wk}$ to

${ }^{3}$ Paired $t$ test. very low levels (Fig. 4). The presence of $d$-glucose in the stored blood (ACD units) permitted maintenance of GSH for a much longer time. Adenine had an added effect in the preservation of GSH. Comparisons by paired $t$ tests showed that at 6 and 8 wk of storage GSH levels in ACD-adenine blood were significantly higher than in paired ACD units $(P>0.01)$. Similar results were recently reported by Arky, Szasz, and Gardos (20). The addition of inosine to $\mathrm{ACD}$-adenine blood had no significant additional effect on GSH levels.

During the first 3 wk of storage, red cell ATP concentrations were well preserved, especially in units containing adenine and adenine-inosine (Fig. 5). In contrast, 2,3-DPG fell rapidly in blood preserved with ACDadenine and somewhat less rapidly in ACD units. Furthermore, 2,3-DPG levels were much better maintained in the presence of inosine. Others have reported similar data on the changes in ATP and 2,3-DPG levels in blood stored with these preservatives (21-24).

Paired units of blood, which had been stored for 20 days in ACD and ACD-adenine, were sampled before and after incubation with inosine (15 $\mu \mathrm{moles} / \mathrm{ml}$ of whole blood) for $60 \mathrm{~min}$ at $37^{\circ} \mathrm{C}$ (Fig. 6). These conditions were previously employed by Shafer and Bartlett (25). In results similar to theirs, a marked rise in red cell 2,3-DPG and ATP levels was noted after incubation. Concomitant with this there was a rise in $P_{50}$ about halfway toward the values found in fresh blood before storage.

Oxygen dissociation curves were run on the same blood specimens before and after hemolysis (Table III). Comparisons were made by two methods. Oxygen dissociation curves were performed by the Van Slyke gasometric method (used in all the experiments reported above) before and after the addition of $3 \mathrm{mg}$ of saponin per $\mathrm{ml}$ of whole blood (the minimum amount necessary for complete hemolysis). In each instance there was a fall in $\mathrm{P}_{50}$ and a rise in $n$ after hemolysis. Gullbring and
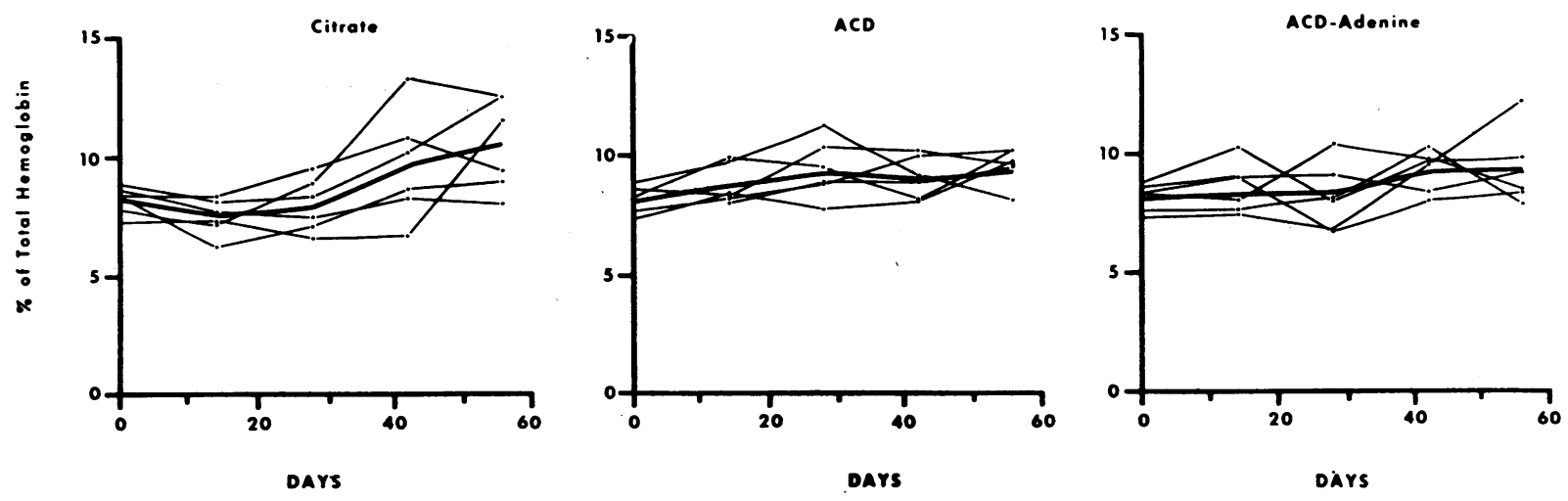

FIGURE 3 A3 hemoglobin levels during storage of blood preserved with "citrate," ACD, and ACD-adenine. The heavy line represents the mean value for each group. 

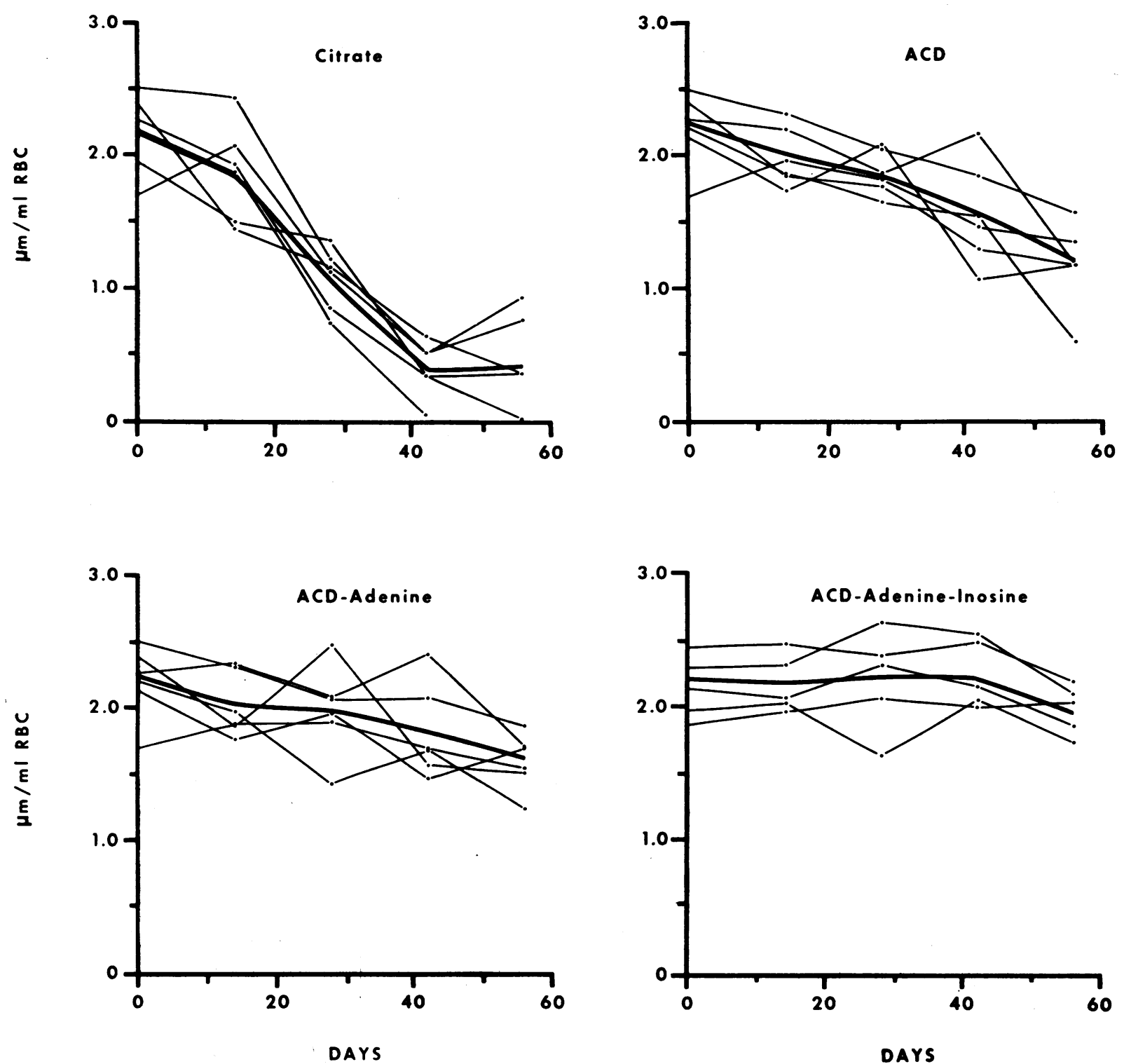

FIGURE 4 Reduced glutathione levels during storage of blood preserved with "citrate," ACD, ACD-adenine, and ACD-adenine-inosine. The heavy line represents the mean value for each group.

Ström also observed an increased in oxygen affinity in blood after saponin lysis, but they did not report $n$ values (9). In a second group, the whole blood oxygen dissociation curve was compared to a curve performed on the hemolysate by a spectrophotometric method. The data shown in Table III are corrected to a temperature of $37^{\circ} \mathrm{C}$. Here again, a lower $\mathrm{P}_{\text {so }}$ and a higher $n$ were noted in the hemolysed specimens.

2,3-DPG and ATP levels were measured in specimens of fresh heparinized blood and again in top and bottom layers after high-speed centrifugation (Table IV). This procedure effectively separates old and young cells according to their different densities. Mean corpuscular hemoglobin concentration (MCHC) was also calculated for each of these samples to demonstrate adequate separation. The results are reported as micromoles of 2,3-DPG and ATP per gram of hemoglobin instead of the usual micromoles per milliliter of $\mathrm{RBC}$, in order to give a truer reflection of the relative concentrations per cell. Two specimens were resuspended after centrifugation and the intermediates remeasured. There was no significant change in 2,3-DPG levels after this maneuver, but ATP levels fell about $20 \%$. The normal values in our laboratory for 2,3-DPG and ATP in micromoles per 

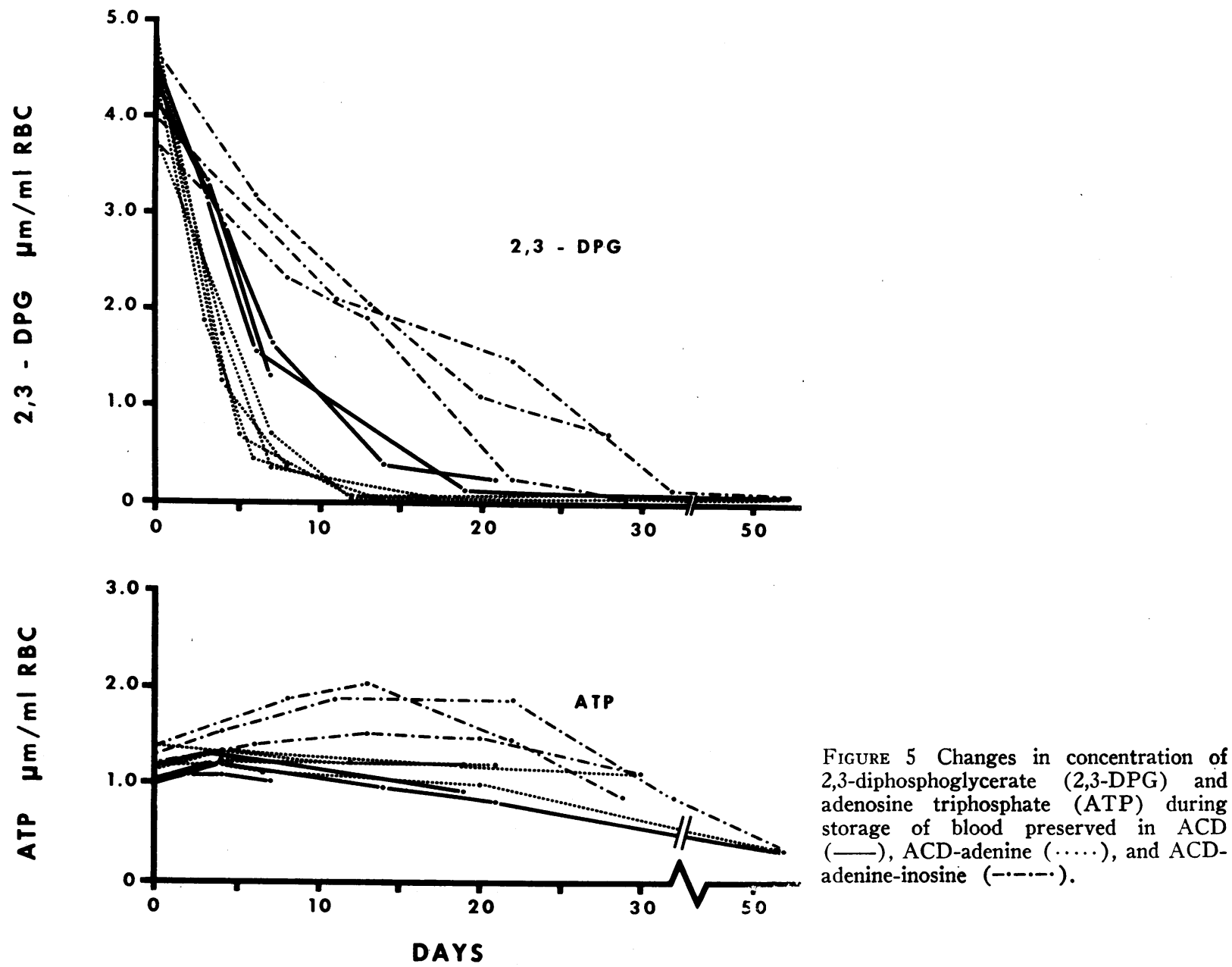

gram of hemoglobin are 13.7 and 4.00 , respectively. As shown in Table IV, the ATP levels in both top and bottom layers were considerably lower than normal, and therefore any difference in ATP between the layers is of questionable significance. In contrast the level of 2,3-DPG in the bottom layer of cells was only slightly lower than normal, while the concentration was $40 \%$ higher in the top layer of red cells. These results suggest that 2,3-DPG concentration falls as red cells age in vivo.

\section{DISCUSSION}

The oxygen dissociation data presented in this report confirm the studies of Valtis and Kennedy (1) and Gullbring and Ström (9) which indicate that oxygen affinity rises during storage of ACD blood resulting in a "shift to the left" of the oxygen dissociation curve. In these earlier studies fresh units were compared with stored units, all from different donors. Because our data were obtained by serial sampling during storage, a much more precise estimate of the timing of this phenomenon was possible. Furthermore, the use of paired units from the same donor allowed a better comparison between different preservatives. The results presented here indicate that oxygen affinity rose even more promptly in the blood preserved with ACD-adenine than in ACD blood. However, when inosine was added to ACD-adenine blood at the time of collection oxygen affinity increased much more slowly. When stored ACD or ACD-adenine blood was incubated with inosine, hemoglobin function was partially restored toward normal.

It was important to explore the various factors which could affect the function of hemoglobin in stored red cells. In the presence of ferrihemoglobin or carboxyhemoglobin, oxygen affinity of the remaining "active" hemoglobin is increased (26). About 20-30\% "inactive" hemoglobin would be required to bring about the degree of increased oxygen affinity observed in stored blood. Since the total accumulation of ferrihemoglobin and carboxyhemoglobin over 30 days of storage was almost 

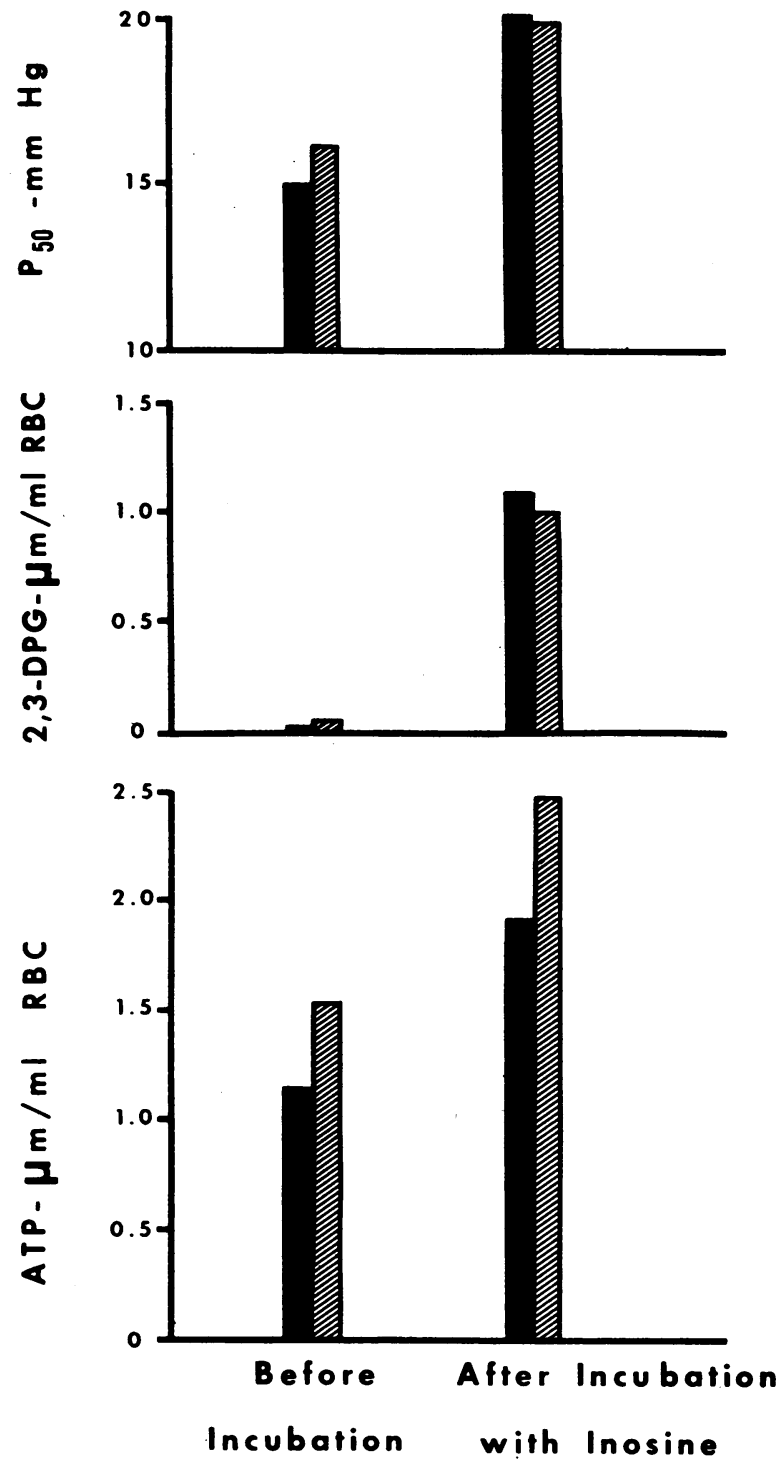

FIGURE 6 Effect of incubation with inosine on the oxygen affinity, 2,3-DPG levels, and ATP levels of 20-day old blood preserved in ACD (solid bars) and ACD-adenine (hatched bars).

certainly less than $2 \%$, the explanation for the altered hemoglobin function of stored blood must lie elsewhere. A3 ( $\left.\mathrm{A}_{\mathrm{I}}\right)$ hemoglobin was measured in units stored with various preservatives. Huisman and Horton have shown that certain subfractions of A3 hemoglobin increase after prolonged storage at $4^{\circ} \mathrm{C}$ or after shorter incubations at $37^{\circ} \mathrm{C}(27)$. Among them was the mixed disulfide of glutathione which like hemoglobin treated with various other sulfhydryl reagents has been found to have an increased oxygen affinity (28). The fact that the total concentration of A3 hemoglobin remained constant throughout 8 wk storage in ACD and ACD- adenine blood, makes it unlikely that any minor electronegative component of hemoglobin was responsible for the "shift to the left" of the oxygen dissociation curve. GSH is present in high concentrations in the red cell. Horejsi and Komarkova have presented evidence that GSH may also act as a mediator of hemogolbin function $(29,30)$. When GSH was added in increasing amounts to whole blood or crude hemolysate, they observed a progressive decrease in oxygen affinity. At a plasma concentration of GSH equal to that found in the red cell, the oxygen dissociation curve was shifted considerably to the right of normal. We have confirmed their finding that glutathione added to dialyzed hemoglobin had no effect on oxygen affinity. Although GSH may have an effect on intracellular hemoglobin function it appears not to be involved in the rapid "shift to the left" that occurs during the 1st wk of storage of ACD or ACD-adenine blood, since GSH levels remained constant for about 4 wk (Fig. 4).

TABLE III

Comparison of $P_{50}$ and $\mathrm{n}$ Values of Whole Blood and Hemolysate

\begin{tabular}{|c|c|c|c|c|c|}
\hline Donor & Specimen* & $\begin{array}{l}\text { Day of } \\
\text { storage }\end{array}$ & Method & $P_{50}$ & $n$ \\
\hline & & & & $m m B g$ & \\
\hline $\mathrm{Bu}$. & $\begin{array}{l}\text { Whole blood } \\
\text { Hemolysate }\end{array}$ & $\mathbf{0}$ & $\begin{array}{l}\text { Gasometric } \\
\text { Gasometric }\end{array}$ & $\begin{array}{l}28.1 \\
22.4\end{array}$ & $\begin{array}{l}2.3 \\
2.4\end{array}$ \\
\hline Bu. & $\begin{array}{l}\text { Whole blood } \\
\text { Hemolysate }\end{array}$ & 0 & $\begin{array}{l}\text { Gasometric } \\
\text { Gasometric }\end{array}$ & $\begin{array}{l}27.2 \\
17.8\end{array}$ & $\begin{array}{l}2.3 \\
2.5\end{array}$ \\
\hline Du. & $\begin{array}{l}\text { Whole blood } \\
\text { Hemolysate }\end{array}$ & $\mathbf{0}$ & $\begin{array}{l}\text { Gasometric } \\
\text { Gasometric }\end{array}$ & $\begin{array}{l}25.1 \\
19.5\end{array}$ & $\begin{array}{l}2.2 \\
3.0\end{array}$ \\
\hline Fo. & $\begin{array}{l}\text { Whole blood } \\
\text { Hemolysate }\end{array}$ & $\mathbf{0}$ & $\begin{array}{l}\text { Gasometric } \\
\text { Gasometric }\end{array}$ & $\begin{array}{l}25.0 \\
21.4\end{array}$ & $\begin{array}{l}2.1 \\
2.4\end{array}$ \\
\hline Ba. & $\begin{array}{l}\text { Whole blood } \\
\text { Hemolysate }\end{array}$ & 0 & $\begin{array}{l}\text { Gasometric } \\
\text { Gasometric }\end{array}$ & $\begin{array}{l}28.2 \\
21.4\end{array}$ & $\begin{array}{l}2.7 \\
3.4\end{array}$ \\
\hline Mi. & $\begin{array}{l}\text { Whole blood } \\
\text { Hemolysate }\end{array}$ & 0 & $\begin{array}{l}\text { Gasometric } \\
\text { Spectrophotometric }\end{array}$ & $\begin{array}{l}25.3 \\
12.3\end{array}$ & $\begin{array}{l}2.1 \\
2.7\end{array}$ \\
\hline St. & $\begin{array}{l}\text { Whole blood } \\
\text { Hemolysate }\end{array}$ & $\mathbf{0}$ & $\begin{array}{l}\text { Gasometric } \\
\text { Spectrophotometric }\end{array}$ & $\begin{array}{l}25.4 \\
11.1\end{array}$ & $\begin{array}{l}2.5 \\
3.1\end{array}$ \\
\hline Bo. & $\begin{array}{l}\text { Whole blood } \\
\text { Hemolysate }\end{array}$ & 0 & $\begin{array}{l}\text { Gasometric } \\
\text { Spectrophotometric }\end{array}$ & $\begin{array}{l}26.0 \\
10.7\end{array}$ & $\begin{array}{l}2.7 \\
2.9\end{array}$ \\
\hline En. & $\begin{array}{l}\text { Whole blood } \\
\text { (ACD) } \\
\text { Hemolysatef }\end{array}$ & $\mathbf{0}$ & $\begin{array}{l}\text { Gasometric } \\
\text { Spectrophotometric }\end{array}$ & $\begin{array}{l}26.3 \\
11.8\end{array}$ & 2.8 \\
\hline & $\begin{array}{l}\text { Whole blood } \\
\text { (ACD) } \\
\text { Hemolysatef }\end{array}$ & 1 & $\begin{array}{l}\text { Gasometric } \\
\text { Spectrophotometric }\end{array}$ & $\begin{array}{l}27.0 \\
10.9\end{array}$ & 1.9 \\
\hline & $\begin{array}{l}\text { Whole blood } \\
\text { (ACD) }\end{array}$ & 3 & Gasometric & 20.0 & 2.0 \\
\hline & Hemolysatef & & Spectrophotometric & 9.8 & 3.0 \\
\hline & $\begin{array}{l}\text { Whole blood } \\
\text { (ACD) } \\
\text { Hemolysatef }\end{array}$ & 7 & Spectrophotometric & 18.0 & 2.4 \\
\hline
\end{tabular}

Pso, partial pressure of oxygen at which hemoglobin is half-saturated. * Blood specimens were anticoagulated with heparin unless stated otherwise.

¥ Hemolysates were prepared the same day the oxygen dissociation curves were run. 
TABLE IV

Levels of 2,3-DPG and ATP in "Young" and "Old" Erythrocytes of Fresh Heparinized Blood, Separated by HighSpeed Centrifugation

\begin{tabular}{|c|c|c|}
\hline Donor & $\begin{array}{c}\text { Top- } \\
\text { layer cells }\end{array}$ & $\begin{array}{l}\text { Bottom- } \\
\text { layer cells }\end{array}$ \\
\hline \multicolumn{3}{|l|}{ Da. } \\
\hline $\mathrm{MCHC}, \mathrm{g} / 100 \mathrm{ml}$ & 32.8 & 36.7 \\
\hline 2,3-DPG, $\mu$ moles $/ \mathrm{g} \mathrm{Hb}$ & 17.3 & 12.2 \\
\hline ATP $\quad "$ & 2.74 & 2.61 \\
\hline \multicolumn{3}{|l|}{$\mathrm{Bu}$} \\
\hline $\mathrm{MCHC}, \mathrm{g} / 100 \mathrm{ml}$ & 31.4 & 34.6 \\
\hline 2,3-DPG, $\mu$ moles $/ \mathrm{g} \mathrm{Hb}$ & 14.3 & 11.1 \\
\hline ATP $\quad "$ & 3.15 & 2.95 \\
\hline \multicolumn{3}{|l|}{ Ba. } \\
\hline MCHC, $g / 100 m l$ & 33.4 & 37.2 \\
\hline 2,3-DPG, $\mu$ moles $/ \mathrm{g} \mathrm{Hb}$ & 14.4 & 12.1 \\
\hline ATP & 4.05 & 3.08 \\
\hline \multicolumn{3}{|l|}{ Fi. } \\
\hline MCHC, $\mathrm{g} / 100 \mathrm{ml}$ & 32.8 & 37.8 \\
\hline 2,3-DPG, $\mu$ moles $/ g \mathrm{Hb}$ & 18.9 & 13.8 \\
\hline ATP $\quad "$ & 2.93 & 2.73 \\
\hline \multicolumn{3}{|l|}{$\mathrm{Ka}$} \\
\hline MCHC, $\mathrm{g} / 100 \mathrm{ml}$ & 32.7 & 33.7 \\
\hline 2,3-DPG, $\mu$ moles/g Hb & 18.4 & 13.4 \\
\hline ATP $\quad "$ & 3.29 & 2.61 \\
\hline \multicolumn{3}{|l|}{ Tu. } \\
\hline MCHC, $\mathrm{g} / 100 \mathrm{ml}$ & 31.0 & 38.7 \\
\hline 2,3-DPG, $\mu$ moles/g $\mathrm{Hb}$ & 17.4 & 10.4 \\
\hline ATP & 3.06 & 1.82 \\
\hline \multicolumn{3}{|l|}{ Du. } \\
\hline MCHC, $g / 100 m l$ & 32.4 & 34.5 \\
\hline 2,3-DPG, $\mu$ moles $/ g \mathrm{Hb}$ & 19.0 & 11.8 \\
\hline ATP $\quad "$ & 4.04 & 2.35 \\
\hline \multicolumn{3}{|l|}{ El. } \\
\hline $\mathrm{MCHC}, \mathrm{g} / 100 \mathrm{ml}$ & 31.1 & 36.5 \\
\hline 2,3-DPG, $\mu$ moles $/ \mathrm{g} \mathrm{Hb}$ & 17.0 & 13.2 \\
\hline ATP $\quad "$ & 2.00 & 2.06 \\
\hline \multicolumn{3}{|l|}{ Mean values } \\
\hline 2,3-DPG, $\mu$ moles $/ \mathrm{g} H b$ & 17.1 & 12.3 \\
\hline ATP $\quad "$ & 3.16 & 2.53 \\
\hline
\end{tabular}

DPG, diphosphoglycerate; ATP, adenosine triphosphate; MCHC, mean corpuscular hemoglobin concentration.

Benesch and Benesch (31) and Chanutin and Curnish (32) have reported that certain phosphorylated intermediates, particularly 2,3-DPG and ATP, have important effects on hemoglobin function. These investigators have found that the addition of 2,3-DPG or ATP to pure hemoglobin solutions results in a progressive decrease in oxygen affinity. 2,3-DPG is present in unusually large concentrations in human red cells. Indeed, the concentration of 2,3-DPG in normal erythrocytes is around $5 \times 10^{-8} \mathrm{~mole} / \mathrm{liter}$, roughly the same as hemoglobin. Unlike, GSH, its physiologic role in the red cell has not been well understood. Benesch. Benesch, and $\mathrm{Yu}$ have found that this substance binds mole for mole specifically with deoxyhemoglobin and have determined an equilibrium constant for this interaction (33). When this constant is appiled to the high hemoglobin concentration present in the red cell, it can be predicted that a marked increase in oxygen affinity will occur when red cell 2,3-DPG concentration falls to half normal. In saponin hemolysates of fresh blood, a rise in oxygen affinity was noted even though the whole blood 2,3-DPG concentration remained unchanged (Table III). Although other explanations are possible, it is likely that the increased affinity in lysed blood results from the lowering of 2,3-DPG and hemoglobin concentrations to less than half that of the intact cell, thereby greatly decreasing the interaction of these two molecules.

The pattern of changes in 2,3-DPG in stored blood (Fig. 5) is closely reflected in alterations in oxygen affinity (Figs. 1 and 2). In Fig. 7 the $P_{\text {so }}$ values for blood stored in ACD, ACD-adenine, and ACD-adenineinosine, measured at various times after collection, are plotted against the sum of the 2,3-DPG and ATP concentrations of the respective specimens. The following $r$ values were obtained: $\mathrm{ACD}, 0.91(\mathrm{n}=14)$; $\mathrm{ACD}$ adenine, $0.90(\mathrm{n}=27)$, ACD-adenine-inosine, $0.88(\mathrm{n}=$ 13). These strong correlations fit the hypothesis that the concentration of 2,3-DPG and ATP is the primary determinant of oxygen affinity of stored blood. Since ATP concentrations changed little during the first 21 days of storage in ACD and ACD-adenine (Fig. 5), there is an equally good correlation between $P_{50}$ values and 2,3DPG levels alone. However, in blood preserved with ACD-adenine-inosine, the rise in ATP levels during the first 2 wk of storage presumably also contributed to the maintenance of low oxygen affinity. Other intracellular substances besides 2,3-DPG (and ATP) may be important in maintaining low oxygen affinity. During storage there is an accumulation of inorganic phosphate, which has been shown to have a similar effect on hemoglobin function, although much weaker than 2,3-DPG and $\operatorname{ATP}(31,32)$.

Valtis and Kennedy have reported a shift to the left in whole blood oxygen dissociation curves of patients immediately after receiving 2 or more units of $A C D$ blood, stored 7 or more days (1). Several hours after transfusion, the oxygen affinity of the patients' blood started to fall toward the pretransfusion level. It is likely that stored red cells begin to resynthesize phosphorylated intermediates soon after transfusion. Using the Ashby technique to recover transfused cells which had been stored in ACD, Valeri and his associates have found 


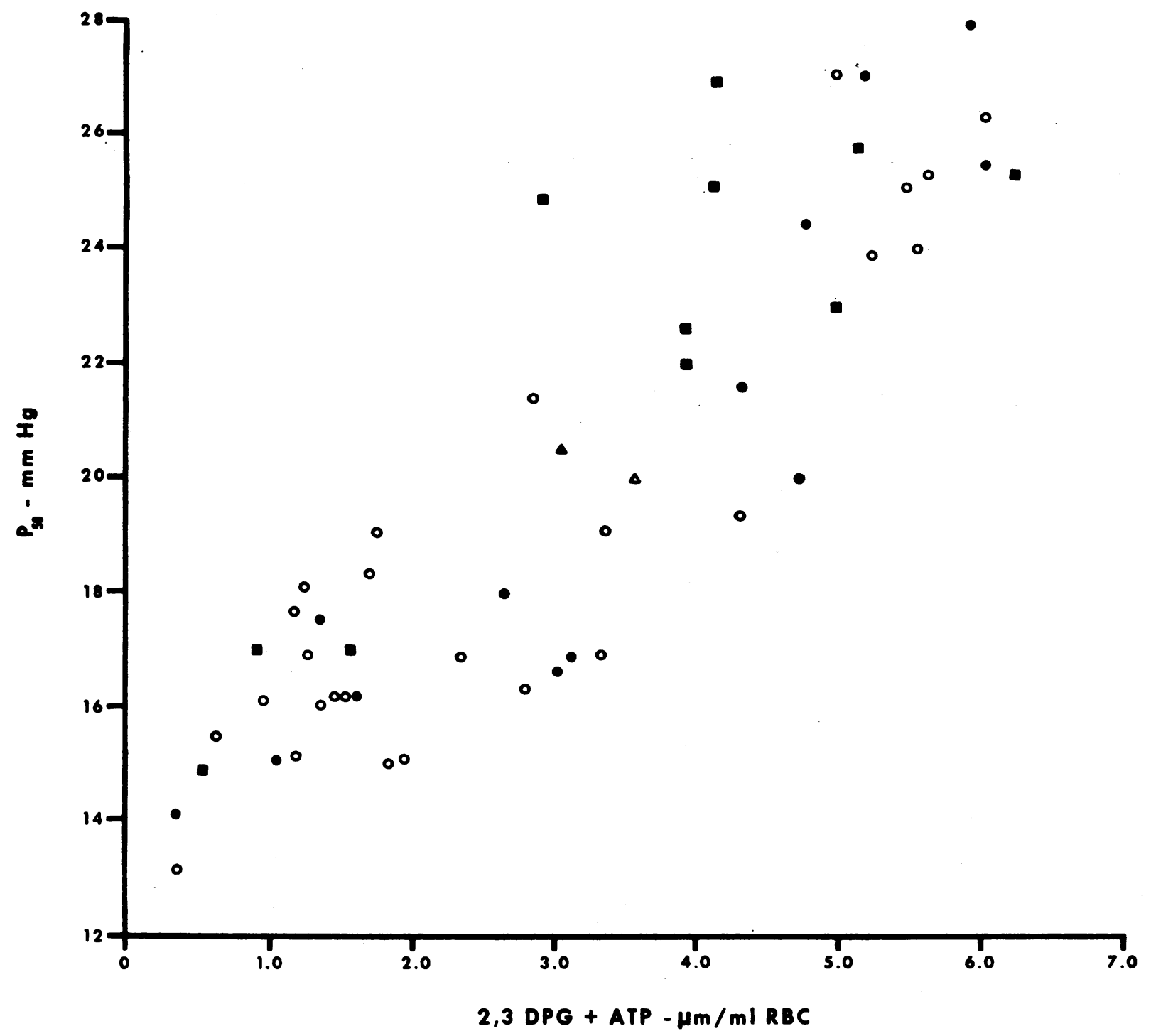

FIGURE 7 Relationship between oxygen affinity and the sum of 2,3-DPG and ATP concentrations in blood preserved in ACD $\bullet, A C D$-adenine $O$, and ACD-adenine-inosine $\boldsymbol{\square} . \boldsymbol{\Delta}=20$ day old ACD blood incubated with inosine. $\triangle=20$ day old ACD-adenine blood incubated with inosine.

that 2,3-DPG levels rose from zero to approximately $1.7 \mu \mathrm{moles} / \mathrm{ml}$ of $\mathrm{RBC}$ within $3 \mathrm{hr}$ after transfusion."

The results from this study allow some conclusions about the measurement and interpretation of Hill's $n$ in whole blood. Many studies have shown that $\boldsymbol{n}$ values for hemoglobin solutions are considerably higher than for whole blood. The data in Table III indicate that this also holds for oxygen dissociation curves on whole blood and saponin hemolysates, performed by the same method. Recent experiments of others suggest a possible explanation. Edwards and Rigas have shown that young red cells (and their hemolysates) have a considerably lower oxygen affinity than old red cells (19). Supranormal $P_{50}$ values were observed in young cells. The fact that this difference disappeared when the hemolysates were dialyzed against salt solutions (but not water) suggested that some small charged molecule was interacting with the hemoglobin. These authors offered 2,3-DPG as a likely explanation. As shown in Table IV, the supranormal 2,3-DPG levels in "young" cells as compared to "old" cells, prepared by the same method employed by Edwards and Rigas, provide support for this hypothesis. In fresh whole blood, as in any mixture containing hemoglobins of varying oxygen affinity, the experimental value for the coefficient $n$ in the Hill equation 
must necessarily be lower than the value for the individual component hemoglobins. For example Benesch and associates showed that hemoglobin partially stripped of 2,3-DPG had an $n$ value considerably less than that of either unstripped or fully stripped hemoglobin (33). Fresh whole blood consists of young red cells that are relatively rich in 2,3-DPG and old cells that are relatively poor. Thus $2,3-\mathrm{DPG}$ is compartmentalized in whole blood. Complete lysis allows even distribution of 2,3-DPG among all hemoglobin molecules. A higher $n$ value would be expected in a more uniform solution. When viewed in this way, it is not surprising that after $3 \mathrm{wk}$ of storage in ACD or ACD-adenine, with the disappearance of 2,3-DPG, there is a significant increase in $n$. In 2 units stored for $8 \mathrm{wk}$, upon depletion of ATP, $n$ values rose even higher.

The therapeutic significance of the increase in oxygen affinity of stored blood is uncertain. It is unlikely that any untoward effect would be observed unless a large number of transfusions was given. In such cases, failure of hemoglobin to unload sufficient oxygen to tissues due to its increased affinity could have important consequences. At the least, the full benefit of transfusion therapy would not be realized. The fact that blood preserved in inosine maintains normal hemoglobin function far longer than the other preservatives tested makes this additive worthy of further attention. 2,3-DPG levels fall more slowly in blood preserved with citrate-phosphate-dextrose (CPD) as compared with ACD (23). Thus a less rapid increase in oxygen affinity would also be expected during storage of CPD blood.

\section{ADDENDUM}

Since this manuscript was submitted, the following report has come to our attention: Akerblom, O., C.-H. de Verdier, L. Garby, and C. Högman. 1968. Restoration of defective oxygen-transport function of stored red blood cells by addition of inosine. Scand J. Clin. Lab. Invest. 21: 245. These authors also found that falling levels of ATP and 2,3-DPG in stored blood correlated closely with increasing oxygen affinity.

\section{ACKNOWLEDGMENTS}

Mrs. Edith Bowles-Ledford, Mrs. Joyce Goetz-Daly, Mr. Thomas Billings, and Specialist 5, Thomas Ellis, provided able technical assistance. We are also indebted to Dr. John Fuller Tayor, University of Louisville School of Medicine, for his invaluable help in setting up the oxygen equilibria techniques and his continued interest in these studies. Lt. Cdr. Alan S. Keitt of the Chelsea Naval Hospital made the facilities of his laboratory available to us for learning the microfluorometric assays. The helpful advice of Dr. Alfred Chanutin, Col. Ralph H. Forrester, and Lt. Col. Frank R. Camp, Jr. is also greatly appreciated.

\section{REFERENCES}

1. Valtis, D. J., and A. C. Kennedy. 1954. Defective gastransport function of stored red blood-cells. Lancet. 1: 119.
2. Shields, C. E. 1968. Comparison studies of whole blood stored in ACD and CPD and with Adenine. Transfusion (Philadelphia). 8: 1 .

3. Simon, E. R., R. G. Chapman, and C. A. Finch. 1962. Adenine in red cell preservation. J. Clin. Invest. 41: 351.

4. de Verdier, C. H., L. Garby, M. Hjelm, and C. Högman. 1964. Adenine in blood preservation: post-transfusion viability and biochemical changes. Transfusion (Philadelphia). 4: 331 .

5. Peters, J. P., and D. D. Van Slyke. 1932. Gasometric methods for analysis of blood and other solutions. In Quantitative Clinical Chemistry. Williams \& Wilkins Co., Baltimore. 2: 229.

6. Bunn, H. F., M. H. May, D. Lenzi, and J. F. Taylor. 1968. An adaptation of the Peters and Van Slyke method for measuring whole blood oxygen dissociation equilibria. U. S. Army Medical Research Laboratory, Fort Knox, Ky. Report No. 785.

7. Severinghaus, J. W. 1958. Oxyhemoglobin dissociation curve correction for temperature and $\mathrm{pH}$ variation in human blood. J. Appl. Physiol. 12: 485.

8. Ayres, S. M., S. Gianelli, Jr., and R. G. Armstrong. 1965. Carboxyhemoglobin: hemodynamic and respiratory responses to small concentrations. Science. 149: 193.

9. Gullbring, B., and G. Ström. 1956. Changes in oxygencarrying function of human hemoglobin during storage in cold acid-citrate-dextrose solution. Acta Med. Scand. 155 : 413.

10. Bromberg, P. A., and W. N. Jensen. 1967. Blood oxygen dissociation curves in sickle cell disease. J. Lab. Clin. Med. 70: 480 .

11. Bartels, H., K. Betke, P. Hilpert, G. Niemeyer, and K. Riegel. 1961. Die sogenannte Standard- $\mathrm{O}_{2}$-Dissoziationskurve des gesunden erwachsenen Menschen. Pfuegers Arch. Gesamte Physiol. Menschen Tiere. 272: 372.

12. Rossi Fanelli, A., and E. Antonini. 1958. Studies on the oxygen and carbon monoxide equilibria of human myoglobin. Arch. Biochem. Biophys. 77: 478.

13. Lowry, O., J. V. Passonneau, F. X. Hasselberger, and D. W. Schulz. 1964. Effect of ischemia on known substrates and cofactors of the glycolytic pathway in brain. J. Biol. Chem. 239: 18.

14. Keitt, A. S. 1966. Pyruvate kinase deficiency and related disorders of red cell glycolysis. Amer. J. Med. 41: 762.

15. Beutler, E., O. Duron, and B. M. Kelly. 1963. An improved method for the determination of blood glutathione. J. Lab. Clin. Med. 61: 882

16. Jocelyn, P. C. 1960 . The reduction of oxidized glutathione in erythrocyte hemolysates in pernicious anemia. Biochem. J. 77: 363 .

17. Allen, D. W., W. A. Schroeder, and J. Balog. 1958. Observations on the chromatographic heterogeneity of normal adult and fetal human hemoglobin. J. Amer. Chem. Soc. 80 : 1628.

18. Evelyn, K. A., and H. T. Malloy. 1938. Microdetermination of oxyhemoglobin, methemoglobin and sulfhemoglobin in a single sample of blood. J. Biol. Chem. 126: 655.

19. Edwards, M. J., and D. A. Rigas. 1967. Electrolyte labile increase of oxygen affinity during in vivo aging of hemoglobin. J. Clin. Invest. 46: 1579.

20. Arky, I., I. Szasz, and G. Gardos. 1966. Effect of adenine and inosine on the reduced glutathione levels and functional SH-groups of preserved erythrocytes. Haematologica Hung. 6: 57.

21. Rubinstein, D., S. Kashket, and O. F. Denstedt. 1958. Studies on the preservation of blood. IV. The influence 
of adenosine and inosine on the metabolism of the erythrocyte. Can. J. Biochem. 36: 1269.

22. Shafer, A. W., and J. S. Trombold. 1964. Phosphorylated carbohydrate intermediates of the human erythrocyte during storage in acid-citrate-dextrose. IV. Effect of addition of adenine, inosine, inosine-adenine and adenosine at the beginning of storage. Transfusion (Philadelphia). $4: 120$.

23. Chanutin, A. 1967. The effect of the addition of adenine and nucleosides at the beginning of storage on the concentrations of phosphates of human erythrocytes during storage in acid-citrate-dextrose and citrate-phosphatedextrose. Transfusion (Philadelphia). 7: 120.

24. Sugita, Y., and E. R. Simon. 1965. Mechanism of action of adenine in red cell preservation. J. Clin. Invest. 44: 629.

25. Shafer, A. W., and G. R. Bartlett. 1962. Phosphorylated carbohydrate intermediates of the human erythrocyte during storage in acid-citrate-dextrose. III. Effect of incubation at $37^{\circ} \mathrm{C}$ with inosine, inosine plus adenine and adenosine after storage for $6,10,14$, and 18 weeks. J. Clin. Invest. $41: 690$.

26. Darling, R. C., and F. J. W. Roughton. 1942. The effect of methemoglobin on the equilibrium between oxygen and hemoglobin. Amer. J. Physiol. 137: 56.
27. Huisman, T. H. J., and B. F. Horton. 1965. Studies on the heterogeneity of hemoglobin VIII. Chromatographic and electrophoretic investigations of various minor hemoglobin fractions present in normal and in vitro modified red blood cell hemolysates. J. Chromatogr. 18: 116.

28. Taylor, J. F., E. Antonini, M. Brunori, and J. Wyman. 1966. Studies on human hemoglobin treated with various sulfhydryl reagents. J. Biol. Chem. 241: 241.

29. Horejsi, J., and A. Komarkova. 1957. The effect of SHgroups on the affinity of haemoglobin to oxygen. Clin. Chem. Acta. 3: 131

30. Horejsi, J. 1967. Effect of reduced glutathione on the dissociation curve of hemoglobin. Haematologica (Budapest). $1: 35$.

31. Benesch, R., and R. E. Benesch. 1967. The effect of organic phosphates from the human erythrocyte on the allosteric properties of hemoglobin. Biochem. Biophys. Res. Commun. 26: 162.

32. Chanutin, A., and R. R. Curnish. 1967. Effect of organic and inorganic phosphates on the oxygen equilibrium of human erythrocytes. Arch. Biochem. Biophys. 121: 96.

33. Benesch, R., R. E. Benesch, and C. I. Yu. 1968. Reciprocal binding of oxygen and diphosphoglycerate by human hemoglobin. Proc. Nat. Acad. Sci. U.S.A. 59: 526. 